University of New Hampshire

University of New Hampshire Scholars' Repository

$1-3-1994$

\title{
Modern eolian dust deposition in central Asia
}

\author{
Cameron P. Wake \\ University of New Hampshire - Main Campus, cameron.wake@unh.edu
}

Paul A. Mayewski

University of New Hampshire - Main Campus

Dahe Qin

Chinese Academy of Sciences

Follow this and additional works at: https://scholars.unh.edu/earthsci_facpub

\section{Recommended Citation}

Wake CP, PA Mayewski, Z Li, J Han J, D Qin (1994) Modern eolian dust deposition in central Asia. Tellus 46B, 220-233.

This Article is brought to you for free and open access by the Earth Sciences at University of New Hampshire Scholars' Repository. It has been accepted for inclusion in Earth Sciences Scholarship by an authorized administrator of University of New Hampshire Scholars' Repository. For more information, please contact Scholarly.Communication@unh.edu. 


\title{
Modern eolian dust deposition in central Asia
}

\author{
By C. P. WAKE* and P. A. MAYEWSKI, Glacier Research Group, Institute for the Study of Earth, \\ Oceans and Space, University of New Hampshire, Durham, NH 03824, USA, and Z. LI, J. HAN and \\ D. QIN, Lanzhou Institute of Glaciology and Geocryology, Lanzhou 730000, China
}

(Manuscript received 25 August 1993; in final form 3 January 1994)

\begin{abstract}
Glaciers around the globe provide a unique medium for investigating the temporal and spatial variation of dust deposition. Here we investigate the spatial and seasonal distribution of eolian dust deposition in central Asia through the analysis of concentrations and size distributions of insoluble particles (over the size range 1-22 $\mu \mathrm{m}$ diameter) in snow and ice samples collected from eight glaciers in the mountains of central Asia. The sample locations cover a wide geographic area and fall within 4 distinct landscape/climate zones: the southern slopes of the eastern Himalaya; the Karakoram; south eastern Tibetan Plateau; northern/western Tibetan Plateau. Snow samples from each of the 4 landscape/climatic zone displays distinct dust deposition characteristics which are dependent upon the physiographic location of the sampling site with respect to source regions of dust and atmospheric transport pathways. The southern slopes of the eastern Himalaya show very low particle concentrations and low annual dust deposition. This region is relatively free from the influence of Asian dust. The Karakoram appears to be a major sink for particles less than $2 \mu \mathrm{m}$ in diameter which have been transported long distances with the westerly jet stream. Glaciers in the south eastern Tibetan Plateau record the influx of dust generated in the arid and semi-arid regions to the west. Glaciers on the northern and western margin of the Tibetan Plateau lie adjacent to vast arid and semi-arid regions of western China and provide dust depostion records mainly of local significance. Our results suggest that high elevation glaciers in the eastern Himalaya, Karakoram and the south eastern Tibetan Plateau are those most likely to provide longer term dust deposition records which reflect regional to hemispheric signals.
\end{abstract}

\section{Introduction}

Dust derived from the arid and semi-arid regions of the globe is an important component of Earth's tropospheric aerosol burden (Junge, 1979; Prospero et al., 1983; Schütz et al., 1990). While the Sahara is the single largest global source (Morales, 1979; Schütz, 1980; Middleton et al., 1986), deserts of the Asian continent are also a significant source of airborne dust in the northern hemisphere. However, our knowledge of Asian dust originates primarily from atmospheric and ocean sediment sampling programs distant from the source. For example, during the spring, large

\footnotetext{
* Corresponding author.
}

quantities of dust are transported from the deserts of western China to eastern China (Liu et al., 1981; Gao et al., 1992a) Japan (Iwasaka et al., 1983; Inoue and Naruse, 1987), the Pacific Ocean (e.g., Duce et al., 1980; Parrington et al., 1983; Blank et al., 1985; Rea et al., 1985; Uematsu et al., 1985; Merrill et al., 1989; Gao et al., 1992b) and the Canadian Arctic (Rahn et al., 1977; Welch et al., 1991). Dust storms are also a frequent occurrence in southwest Asia (Middleton, 1989). Despite the large quantities of mineral aerosol generated in central Asia, little is known concerning the nature of eolian dust closer to the source regions.

Glaciers around the globe provide a unique medium to investigate temporal and spatial variations of dust deposition.' The highest resolution proxy records extending back $10^{2}$ to $10^{5}$ years 
detailing atmospheric dust content have been developed through the analysis of insoluble particle concentration of ice cores recovered from, for example, Antarctica (e.g., De Angelis et al., 1987; Petit et al., 1990), Greenland (e.g., Hammer et al., 1985; Palais et al., 1992; Fiacco et al., 1993), the Canadian Arctic (e.g., Koerner, 1977), the Swiss Alps (Wagenbach and Geis, 1989), India (Mayewski et al., 1984), and China (Thompson et al., 1989). Windom (1969) measured the dust content in snow from glaciers in North and Central America, and New Zealand, in order to compare continental and oceanic dust deposition rates.

The vast extent of glaciers in the mountains of central Asia provide a convenient means to measure the depositional flux of atmospheric dust over a wide geographic area. Over the past several years we have collected snow, ice and aerosol samples from glacier basins throughout central Asia (Mayewski et al., 1984; Wake, 1989; Wake et al., $1990 ; 1992 ; 1993$; in press). Our results indicate that the spatial variation of snow chemistry in the mountains of central Asia is controlled primarily by the influx of desert dust derived from the arid and semi-arid regions of Asia. Glaciers close to, and downwind of, large desert basins show high concentrations of major ions in snow and aerosol samples, while glaciers distant from source regions of dust show significantly lower ion burdens. Snow samples from the southern slopes of the eastern Himalaya display very low ion concentrations and are relatively free from the dominating chemical influence of Asia dust. Here we report on the regional distribution in the concentration and size distribution of mineral aerosol in central Asian snow and ice and use this data to determine dust deposition characteristics and quantify the annual rate of dust deposition in four physiographic regions in the highlands of central Asia.

\section{Description of sampling sites and dust source areas}

\subsection{Landscape/vegetation zones and climatic regimes}

The sample collection sites cover a wide geographic area (Fig. 1) and can be separated into four distinct regions on the basis of their landscape, as defined by Alekseyev et al. (1988), and/or on the basis of their climatic regime (i.e., relative influence of monsoonal versus westerly air masses) as reviewed by Ramage (1981), Barry and Chorley (1982), Hastenrath (1985), and Domrös and Peng (1988):

(1) Ngozumpa Glacier (Fig. 1, site 1) lies on the southern slopes of the eastern Himalaya. Mixed forest and small scale agriculture dominate below $4500 \mathrm{~m}$ asl, while glaciers and mountains dominate above this elevation. Precipitation is derived from monsoonal air masses during the summer and from westerly depressions during the winter (Inoue, 1976; Barry, 1981).

(2) Hispar Glacier (site 3) lies in the central regions of the Karakoram. The exceptional elevation and concentration of peaks over $6000 \mathrm{~m}$ asl in the Karakoram produces an effective barrier for air masses transported with the mid-latitude westerlies. Orographic lifting of westerly derived air masses throughout the year results in very high snow accumulation rates above $4000 \mathrm{~m}$ asl (Wake, 1989). Occasionally, substantial summer snowfalls result from the incursion of monsoonal air masses (Finsterwalder, 1960; Wake, 1989). Arid and semiarid conditions predominate below $4000 \mathrm{~m}$ asl due to the rainshadow effect and desiccating downvalley wind systems.

(3) Xixabangma Peak (site 4), Qiang Yong Glacier (site 5), and Mt. Geladaindong (site 6) all fall within the grassland steppes which dominate the southern and central regions of the eastern Tibetan Plateau. This region receives most of its precipitation from summer plateau monsoon circulation (Murakami, 1976).

(4) The northern and western regions of the Tibetan Plateau are characterized by semi-arid and arid regions. The Dunde Ice Cap (site 11) lies adjacent to, and Meikuang Glacier (site 7) lies $200 \mathrm{~km}$ south of, the Qaidam Basin in the north eastern regions of the plateau. Mustagh Ata (site 8 ) and Chongce Ice Cap (site 9) lie adjacent to the Taklamakan desert and numerous loess deposits (Liu, 1985).

\subsection{Source areas for dust in Asia}

Descriptions of dust storm activity around the globe are provided by Goudie (1983), Middleton et al. (1986) and Middleton (1986; 1989). Several arid and semi-arid regions act as source areas for 


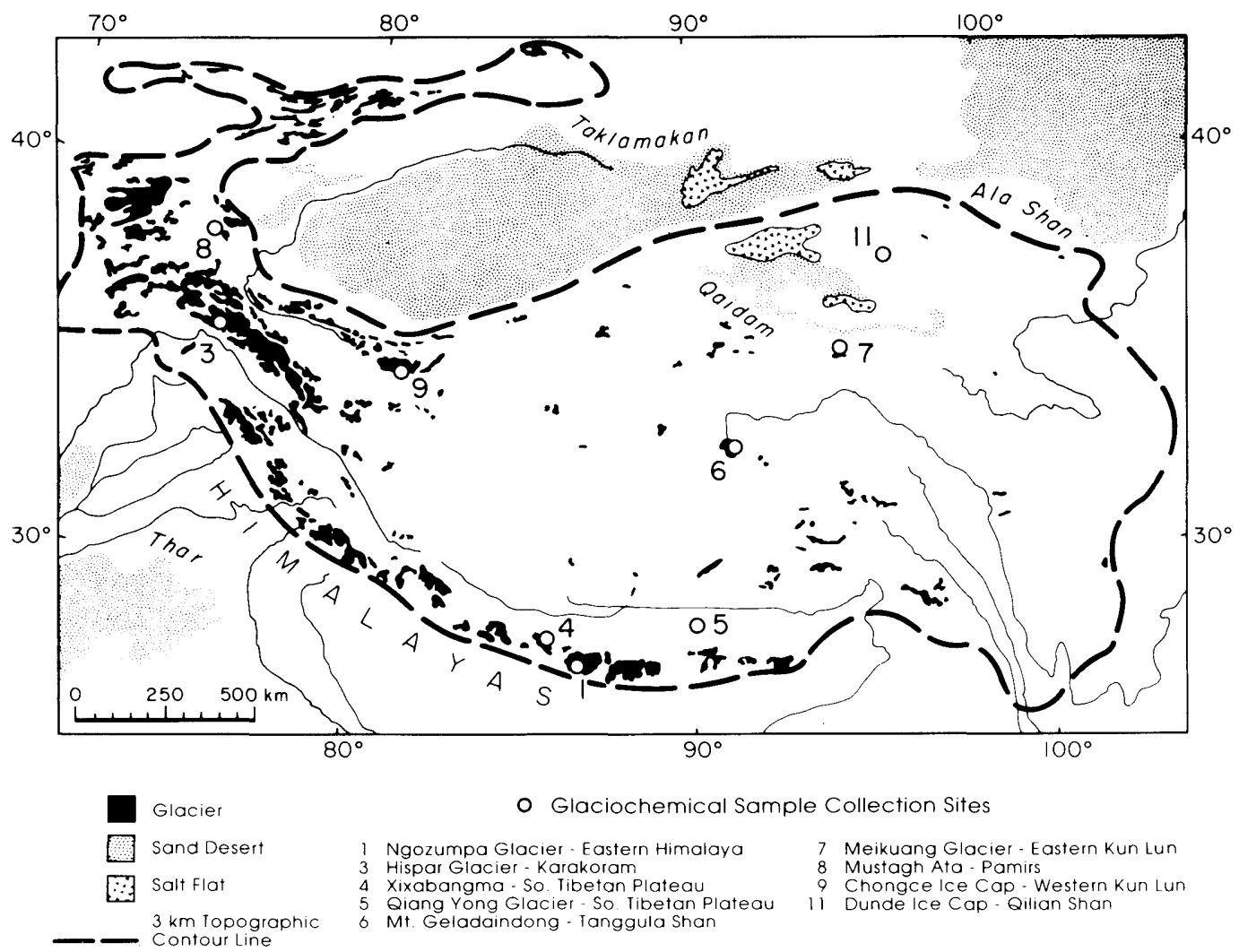

Fig. 1. Location map identifying glaciers where snow and ice samples were collected for microparticle analysis. Site numbers follow the same pattern as those presented in Wake et al. (1993). The heavy dashed line represents the $3000 \mathrm{~m}$ contour and outlines the Tibetan Plateau. All samples were collected within the accumulation zone of each glacier basin. Landscape and topographic information were derived from Royal Geographic Society (1987).

dust in central Asia. Low pressure fronts transport dust from the arid regions in western China (i.e., Taklamakan Desert and surrounding loess deposits, and the Qaidam Basin) eastward over the Tibetan Plateau, eastern China and the Pacific Ocean. Upper level westerly airflow generates point-source dust storms in the western and northern regions of the Tibetan Plateau. Low pressure fronts moving easterly also create dust storm conditions in the Kara Kum and other deserts in Tajikistan, Kyrgyzstan and southern Kazakhstan. In the Thar desert of India and Pakistan, dust is transported easterly and northeasterly as a result of strong pressure gradients prior to the break of the summer monsoon. Katabatic winds, reinforced by topographic funneling of westerlies, generate point-source dust storms in the Karakoram and
Hindu Kush mountain ranges. The peak in dust storm activity throughout Asia occurs during the spring and early summer months, although dust storms do occur at other times of the year.

\section{Sampling and analysis}

\subsection{Sample collection}

Snow and ice samples for this study were collected from snowpits and shallow cores at high elevation sites ( $>5100 \mathrm{~m}$ asl) in the accumulation zones of central Asian glaciers (Table 1). Continuous records of dust deposition extending for one year or longer were recovered from Ngozumpa Glacier, Hispar Glacier, Xixabangma Peak, Qiang 
Table 1. Snow and ice sample collection sites in the mountains of central Asia

\begin{tabular}{rllcccc}
\hline $\begin{array}{c}\text { Site no. } \\
\text { (Fig. 1) }\end{array}$ & $\begin{array}{c}\text { Mountain/ } \\
\text { glacier }\end{array}$ & Mountain range & $\begin{array}{c}\text { Elev. } \\
(\mathrm{m} \text { a.s.1.) }\end{array}$ & $\begin{array}{c}\text { Lat. } \\
(\mathrm{N})\end{array}$ & $\begin{array}{c}\text { Long. } \\
(\mathrm{E})\end{array}$ & $\begin{array}{c}\text { Sample } \\
\text { collection date }\end{array}$ \\
\hline 1 & Ngozumpa Glacier & Himalaya (S. slope) & 5700 & 28.0 & 86.7 & Oct. 1990 \\
3 & Hispar Glacier & Karakoram & 5150 & 36.0 & 75.5 & July 1988 \\
& & & & & \\
4 & Xixabangma Peak & So. Tibetan Plateau & 6140 & 28.3 & 85.7 & Sept. 1991 \\
5 & Qiang Yong Glacier & So. Tibetan Plateau & 5850 & 28.8 & 90.2 & Oct. 1992 \\
6 & Mt. Geladaindong & Tanggula Shan & 5950 & 33.4 & 91.1 & July 1990 \\
& & & & & \\
7 & Meikuang Glacier & Eastern Kun Lun & $5480-5770$ & 35.7 & 94.2 & Aug. 1990 \\
8 & Mustagh Ata & Pamirs & 5910 & 38.2 & 75.1 & Oct. 1992 \\
9 & Chongce Glacier & Western Kun Lun & 6327 & 35.2 & 81.1 & July 1987 \\
11 & Dunde Ice Cap* & Qilian Shan & 5325 & 38.1 & 96.4 & $1984 *$ \\
\hline
\end{tabular}

* Samples from Dunde Ice Cap were collected and analyzed by Thompson et al. (1988).

Yong Glacier, Mt. Geladaindong and Mustagh Ata. Even at $5760 \mathrm{~m}$ on Meikuang Glacier, we sampled shallow snowpacks $(<0.2 \mathrm{~m}$ water equivalent) which lay directly on top of glacier ice. Seasonal snow accumulation melts completely during the summer ablation season. The record at Meikuang Glacier therefore extends for less than one year. The discontinuous record developed from a firn/ice core recovered from Chongce Ice Cap (Han et al., 1989) does not allow for accurate calculation of annual water or dust flux.

Extreme care was taken at all times during sample collection, handling, transport, and analysis to ensure sample integrity. Non-particulating clean suits and hoods, plastic gloves and particle masks were worn during all sampling procedures. Continuous samples were collected over 5 or $10 \mathrm{~cm}$ intervals. This corresponds to more than 10 samples per annual layer of snow at every site. Samples from Ngozumpa Glacier, Xixabangma Peak, Qiang Yong Glacier, Meikuang Glacier, and Chongce Ice Cap were returned to the laboratory in a frozen state. These samples were melted for ion analysis and the remaining sample was frozen until just prior to microparticle analysis. The snow samples from Hispar Glacier and Mustagh Ata were melted in the field and transferred into $30 \mathrm{ml}$ polyethylene vials for transport. Upon arrival at the University of New Hampshire these samples were refrozen and melted just prior to microparticle analysis.

\subsection{Microparticle analyses}

Size distributions of particle concentrations were measured in a Class 100 clean room using an Elzone 280PC particle counter (Fiacco, 1991). The samples were melted in a hot water bath and prepared for analysis by combining $10 \mathrm{ml}$ of the sample with $2.5 \mathrm{ml}$ of filtered, $2.08 \mathrm{~g} \mathrm{ml}^{-1} \mathrm{NaCl}$ solution. This procedure results in an electrolyte solution with a concentration similar to the $14 \%$ $\mathrm{NaCl}$ (by weight) solution used in the instrument.

The Elzone particle counter measures the equivalent spherical diameter of insoluble particles immersed in a dilute electrolyte solution. As a non-conductive particle passes through a circular orafice, it displaces an amount of electrolyte proportional to its volume and acts as a resistance to the normal unobstructed electrical current that flows between two electrodes on either side. The amplitude of the resistance is proportional to the mean diameter of a spherical particle. The particle size distribution is divided into 64 channels, the lowest 5 of which are ignored due to high instrument noise. Blanks, consisting of filtered Milli-Q water (Millipore Corp., Bedford, MA, USA) and concentrated electrolyte, were analyzed prior to sample analysis. Each sample was analyzed in triplicate in order to ensure reproducibility.

The samples from Ngozumpa Glacier, which show relatively low concentrations, were analyzed using a $30.3 \mu \mathrm{m}$ orifice (which measures particles 
in the size range from 0.65 to $13 \mu \mathrm{m}$ ) and a sample volume of $19.5 \mu \mathrm{l}$. The samples from all other sites have much higher particle concentrations as well as several particles with diameters large enough to block the $30.3 \mu \mathrm{m}$ orifice. These samples were analyzed using a $48 \mu \mathrm{m}$ orifice (which measures particles in the size range from 0.98 to $22 \mu \mathrm{m}$ ) and a sample volume of $99.9 \mu 1$.

The mass of an average particle in each size range was calculated by multiplying the mean spherical particle volume by an assumed particle density of $2.6 \mathrm{~g} \mathrm{~cm}^{-3}$, which represents an average value for crustal derived material transported by the wind (Pye, 1987). Particle mass for each size distribution was then determined by multiplying the mass of a mean sized particle by the number concentration. The mass of each sample represents the sum of the mass in each size distribution interval.

Following sample analysis on the Elzone particle counter, several samples were filtered through $0.22 \mu \mathrm{m}$ Durapore (Millipore Corp., Bedford, MA, USA) filters. Five of these filters were observed using an Amray 1000A scanning electron microscope. Almost all of the particles in these samples appeared to be mineral particles.

\section{Results}

\subsection{Depth profiles}

Annual layers in the glacier were delineated in the field using the location of visible dust layers, ice layers and ice lenses, as well as variations in snow density, snow color and grain size. In addition, available meteorological records for each region were reviewed and patterns of seasonal precipitation identified to help delineate seasonal layers. Following analyses of major ion and particle concentrations of snow samples, depth profiles of these parameters were compared with each other, and with the chronology that had been established using the physical characteristics of the snowpack. Strong seasonal signals in chemistry and particle concentrations were then used to help define transitions between different seasonal layers in the glacier. The depth profiles of particle concentrations for continuous records extending longer than one year are illustrated in Fig. 2. End of summer surfaces, as determined from both physical and
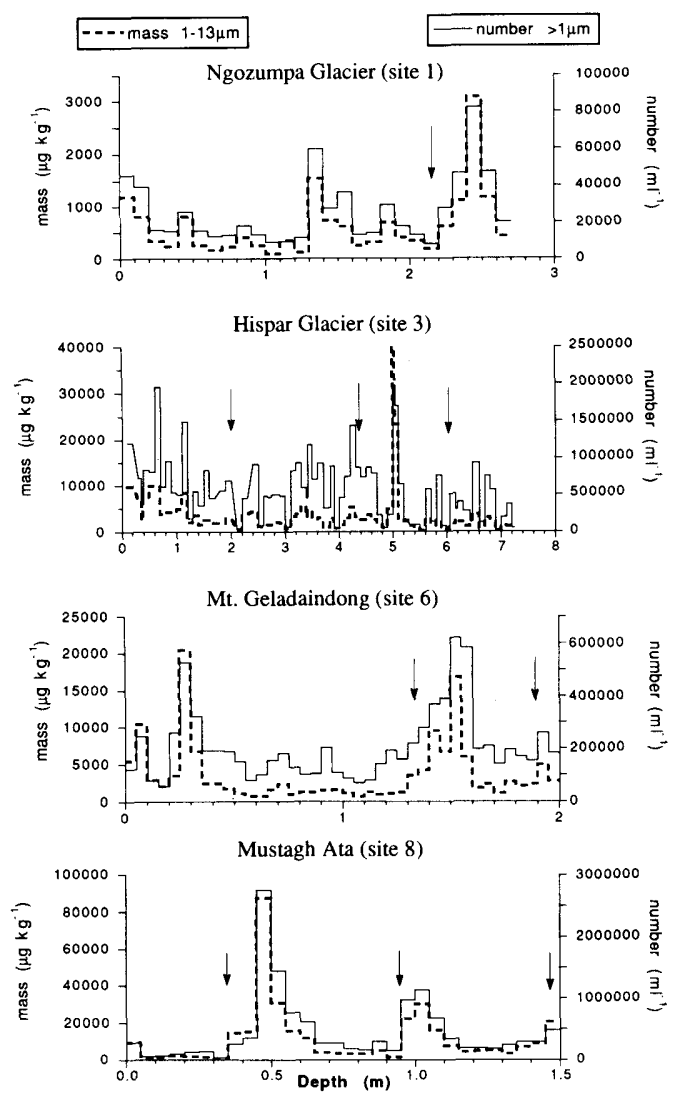

Fig. 2. Depth profiles of particle mass concentrations $(1-13 \mu \mathrm{m})$ and particle number $(>1 \mu \mathrm{m})$ and for snow samples recovered from snowpits excavated on four glaciers in the mountains of central Asia. Arrows mark the "end of summer" surfaces (see text for explanation).

chemical stratigraphy, are identified with vertical arrows.

Among the depth profiles which extend longer than one year, both number and mass concentrations (Fig. 2) show distinct seasonal signals at Ngozumpa Glacier, Mt. Geladaindong, and Mustagh Ata. At Ngozumpa Glacier, layers with high particle concentrations occur twice each year. This is the result of 2 distinct snow accumulation seasons; summer snow derived from monsoonal circulation and winter snow derived from westerly disturbances (Miller et al., 1965; Barry, 1981; Inoue, 1976). At Mt. Geladaindong and Mustagh Ata the annual maximum particle concentrations occur once per year and are interpreted as representing the influx of dust during the spring 
dust storm period. In contrast to the other sites, particle concentrations show no distinct seasonal distribution at Hispar Glacier; instead concentrations peak 3 to 4 times per year.

\subsection{Regional characteristics of dust deposition}

Number- and mass-size distributions have proven extremely useful for characterizing mineral aerosols collected in, for example, Europe (e.g., Junge, 1963), the Sahara (Schütz and Jaenicke, 1974), the Swiss Alps (Wagenbach and Geis, 1989), Colorado and Texas (Patterson and Gillette, 1977), Tajikistan (Gomes and Gillette, in review) and Greenland (Steffensen, 1985). Number-size distributions for each site (Fig. 3) are presented using $\mathrm{d} N / \mathrm{d}(\log D)$, where $N$ is the number of particles per $\mathrm{ml}$ of sample, and $D$ is particle diameter in $\mu \mathrm{m}$, for each size interval. Mass-size distributions (Fig. 4) are presented using $\mathrm{d} M / \mathrm{d}(\log D)$ where $M$ is the mass of particles in $\mu \mathrm{g} / \mathrm{kg}$ of sample for each size interval.

Each of the four broad physiographic regions discussed above display distinct signatures in their particle number concentrations and size distributions, particle mass concentrations and size distributions, and annual rate of dust deposition. The regional variation of these physical properties are presented below.

Number concentrations and size distributions. The mean size-distributions for particle data from all sites show a logarithmic decrease with increasing grain size for particle diameters ranging from 1 to $22 \mu \mathrm{m}$ (Fig. 3). In this regard the distributions show similarities to the Junge distribution for continental aerosols (Junge, 1963). The geometric mean number concentrations for particles with diameters $>2 \mu \mathrm{m}$ (Table 2) were determined in order to compare our data with that available from the Dunde Ice Cap (site 11; Fig. 1) (Thompson et al., 1988).

Ngozumpa Glacier shows relatively low particle number concentrations and a distribution which is similar to that for samples from the last 1300 years recovered from the GISP2 ice core in central Greenland (G. Mershon; pers. comm). Hispar Glacier shows a unique particle distribution with very high number concentrations for particles with diameters of $1-2 \mu \mathrm{m}$. The number-size distribution shows a distinct upward bulge for particles with diameters $<2 \mu \mathrm{m}$ (Fig. 3). Glaciers in the south eastern regions of the Tibetan Plateau (Xixabangma, Qiang Yong and Mt. Geladaindong) display particle number concentrations 3 to 9 times higher than those at Ngozumpa Glacier. Glaciers which lie adjacent to large desert basins in western (Mustagh Ata and Chongce) and north eastern (Dunde) regions of the Tibetan Plateau show number concentrations for particle diameters $>2 \mu \mathrm{m}$ which are greater than glaciers in the south eastern regions of the Tibetan Plateau. The number-size distributions for particles from Mustagh Ata and Chongce Ice Cap show a noticeable departure (concave down) from a loglinear distribution.
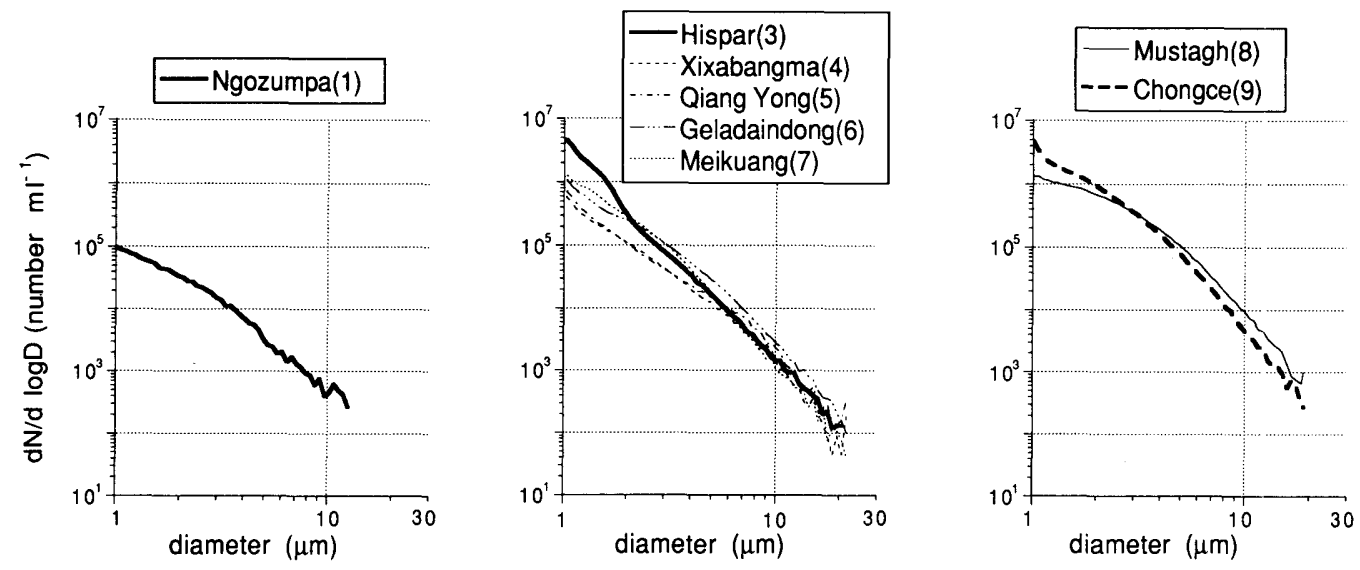

Fig. 3. Mean number-size particle distributions for snow samples collected from 8 glaciers in the mountains of central Asia. The numbers in parentheses refer to location in Fig. 1. 
Table 2. Geometric mean* microparticle concentrations measured in central Asian snow

\begin{tabular}{|c|c|c|c|c|c|c|c|}
\hline \multirow{2}{*}{$\begin{array}{l}\text { Site no. } \\
\text { (Fig. 1) }\end{array}$} & \multirow{2}{*}{$\begin{array}{l}\text { Mountain/ } \\
\text { glacier }\end{array}$} & \multirow{2}{*}{$\begin{array}{l}\text { Period of } \\
\text { record }\end{array}$} & \multirow[b]{2}{*}{$n$} & \multicolumn{2}{|c|}{$\begin{array}{l}\text { no. of particles } \\
\left(\times 10^{3}\right) \mathrm{ml}^{-1}\end{array}$} & \multicolumn{2}{|c|}{$\begin{array}{l}\text { mass of particles** } \\
\qquad\left(\mu \mathrm{g} \mathrm{g}^{-1}\right)\end{array}$} \\
\hline & & & & $1-2 \mu \mathrm{m}$ & $>2 \mu \mathrm{m}$ & $1-13 \mu \mathrm{m}$ & $1-22 \mu \mathrm{m}$ \\
\hline 1 & Ngozumpa & $1989-90$ & 23 & 14.1 & 4.07 & 0.379 & $\mathrm{nd}^{\S}$ \\
\hline 3 & Hispar & $1985-88$ & 81 & 357 & 17.4 & 2.28 & 2.66 \\
\hline 4 & Xixabangma & $1990-91$ & 27 & 83.8 & 18.5 & 1.84 & 2.30 \\
\hline 5 & Qiang Yong & $1990-91$ & 16 & 75.7 & 14.6 & 1.67 & 1.95 \\
\hline 6 & Geladaindong & $1988-90$ & 40 & 133 & 32.3 & 2.32 & 2.63 \\
\hline 7 & Meikuang & Summer '91 & 12 & 178 & 35.5 & 2.14 & 2.30 \\
\hline 8 & Mustagh Ata & 1990-92 & 30 & 202 & 74.4 & 6.10 & 6.78 \\
\hline 9 & Chongce $^{\mathrm{P}}$ & $1980-87$ & 26 & 499 & 117 & 7.53 & 8.22 \\
\hline 11 & Dunde $^{\circledR}$ & $1981-86$ & 44 & nd & 80.4 & nd & nd \\
\hline
\end{tabular}

Here, nd means no data; $n$ is the number of samples analyzed.

* Geometric means are used as the microparticle concentrations for samples from each site approach a lognormal distribution.

** Mass of particles was calculated assuming a particle density of $2.6 \mathrm{~g} \mathrm{~cm}^{-3}$ (Pye, 1987).

$\S$ Samples from Ngozumpa Glacier were only analyzed for particles in the size range 0.60 to $13 \mu \mathrm{m}$. The geometric mean particle number concentration for the entire size range is $59 \times 10^{3} \mathrm{ml}^{-1}$.

D The chemical record from a firn/ice core recovered from Chongce Ice Cap (Han et al., 1989) is discontinuous due to contamination of firn samples during transport. Only particle data from the ice sections of the core are reported.

(a) Data from the Dunde Ice Cap come from Thompson et al. (1988).

Mass concentrations and size distributions. The geometric mean mass of microparticles from each glacier is presented for two size ranges (Table 2). The mass of particles from 1 to $13 \mu \mathrm{m}$ in diameter is available for sites 1 through 9 and forms the basis for investigating the variation in microparticle mass concentrations between sites. Com- parison of the total mass of particles in the 1 to $22 \mu \mathrm{m}$ diameter size range with those in the 1 to $13 \mu \mathrm{m}$ diameter range shows that the smaller size range accounts for $80 \%$ to $93 \%$ of the total measured mass.

Ngozumpa Glacier shows very low mass concentrations (Table 2 ) and a slight positive slope in
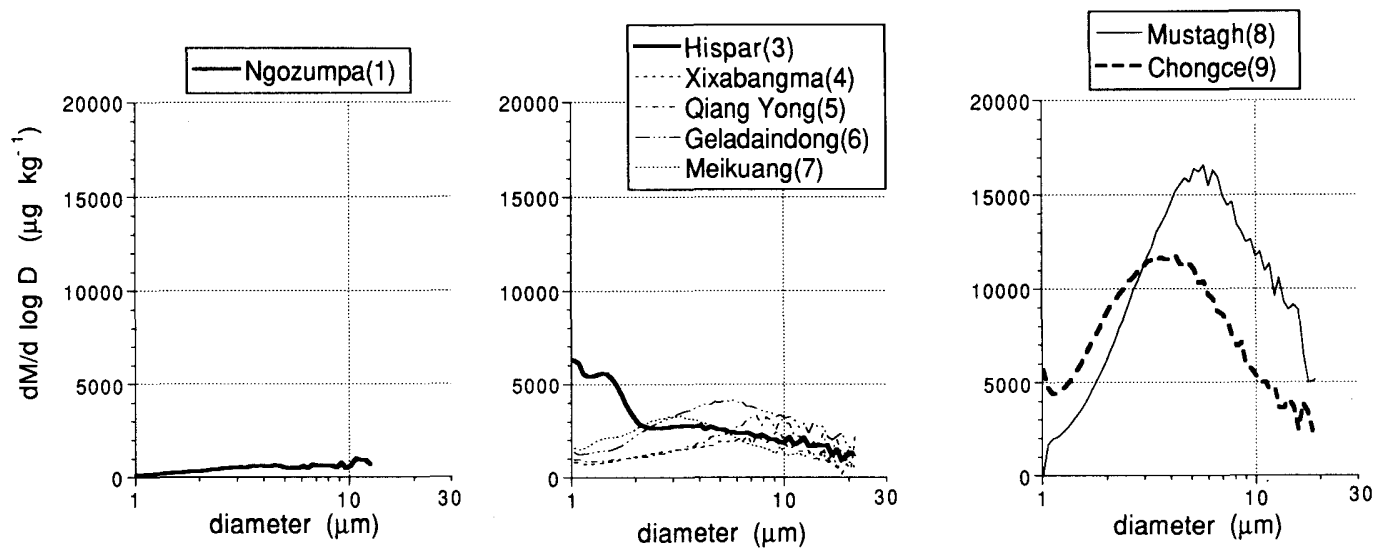

Fig. 4. Mean mass-size particle distributions for snow samples collected from 8 glaciers in the mountains of central Asia. 
the mass-size distribution (Fig. 4). Hispar Glacier shows a mass concentration 6 times greater than that at Ngozumpa Glacier and a bimodal masssize distribution which displays peaks at particle diameters of $<1 \mu \mathrm{m}$ and $1-2 \mu \mathrm{m}$. Glaciers in the south eastern Tibetan Plateau show mass concentrations 4.4 to 6.1 times larger than those at Ngozumpa Glacier and mass-size distributions which display weak peaks between 2 and $8 \mu \mathrm{m}$. Mustagh Ata and Chongce Ice Cap show mass concentrations 2.6 to 4.5 times greater than for glaciers in the south eastern Tibetan Plateau and a lognormal mass size distribution curve which peaks strongly at particle diameters of 3 to $8 \mu \mathrm{m}$.

The mass-size distribution of particles at Hispar Glacier is particularly interesting. Individual samples show one of three different mass size distributions (Fig. 5). 17 samples show a median mass at diameters $<1 \mu \mathrm{m} ; 18$ samples show a median between 1 and $2 \mu \mathrm{m}$. 2 samples display lognormal distributions centered between 3 and $7 \mu \mathrm{m}$. These same two samples show extremely high number and mass concentrations (see samples at $5 \mathrm{~m}$ depth in Fig. 2). The remaining samples ( $n=42$; not shown in Fig. 5) show bimodal mass distributions (with peaks at $<1 \mu \mathrm{m}$ and $1-2 \mu \mathrm{m}$ diameters) or a flat line mass distribution. Samples with peaks in mass-size distributions at $<1 \mu \mathrm{m}$ and $1-2 \mu \mathrm{m}$ are associated with very different concentrations of water soluble ions (Fig. 5); particles with diameters $<1 \mu \mathrm{m}$ are rich in soluble calcium and other soluble ions while 1-2 $\mu$ m diameter particles are relatively inert with respect to soluble chemistry (Wake et al., 1993).

Annual dust deposition. The mass depositional flux of microparticles was calculated by multiplying the water equivalent thickness by the mass concentration in each sample. Annual fluxes represent the sum of fluxes for all samples in an annual layer (Table 3 ).

Ngozumpa Glacier shows the lowest rate of dust deposition. Hispar Glacier shows a relatively high annual dust flux with particle diameters $<2 \mu$ m accounting for half of the annual flux. The annual rate of dust deposition in the south eastern regions of the Tibetan Plateau (Xixabangma, Qiang Yong

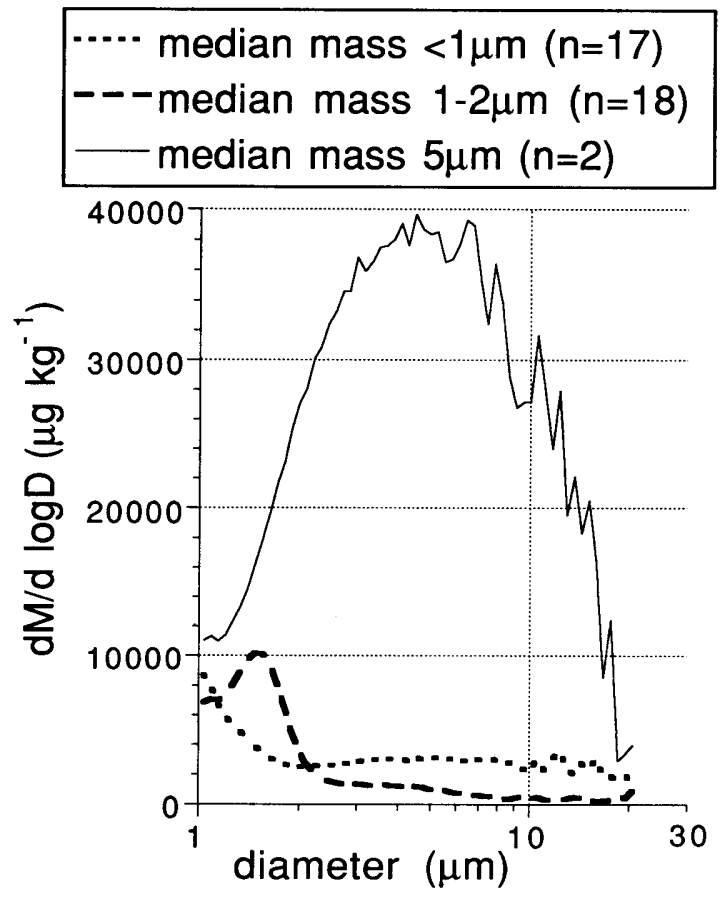

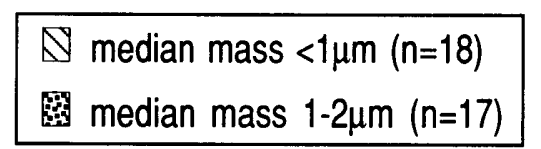

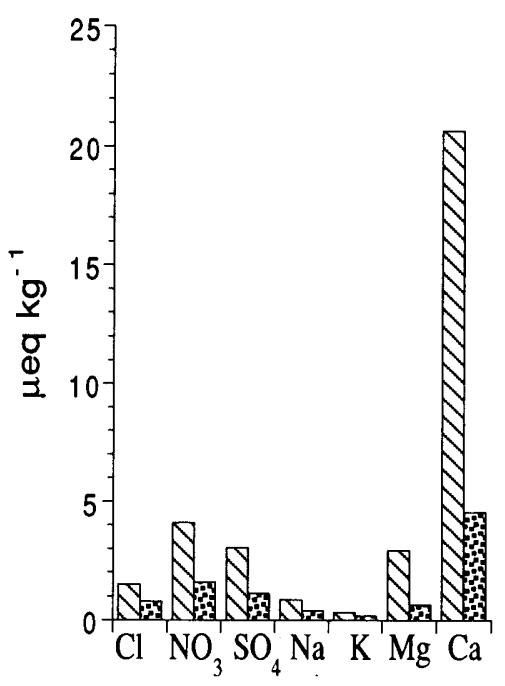

Fig. 5. (a) Three different mass-size distributions, and (b) corresponding soluble ion chemistry for two of the size distributions (from Wake et al., 1993), identified in individual snow samples from Hispar Glacier. 
Table 3. Annual snow accumulation and mass flux of atmospheric dust measured on central Asian glaciers

\begin{tabular}{|c|c|c|c|c|c|}
\hline \multirow{2}{*}{$\begin{array}{l}\text { Site no. } \\
\text { (Fig. 1) }\end{array}$} & \multirow{2}{*}{$\begin{array}{l}\text { Mountain/ } \\
\text { glacier }\end{array}$} & \multirow[b]{2}{*}{ Period* } & \multirow{2}{*}{$\frac{\begin{array}{c}\text { Net snow } \\
\text { accumulation }\end{array}}{\left(\mathrm{g} \mathrm{cm}^{-2} \mathrm{yr}^{-1}\right)}$} & \multicolumn{2}{|c|}{$\begin{array}{l}\text { Dust deposition } \\
\left(\mu \mathrm{g} \mathrm{cm}^{-2} \mathrm{yr}^{-1}\right)\end{array}$} \\
\hline & & & & $1-13 \mu \mathrm{m}$ & $1-22 \mu \mathrm{m}$ \\
\hline 1 & Ngozumpa & $1989-90$ & 57 & 27 & - \\
\hline 3 & Hispar & $\begin{array}{l}1985-86 \\
1986-87 \\
1987-88\end{array}$ & $\begin{array}{l}146 \\
135 \\
116\end{array}$ & $\begin{array}{l}374 \\
385 \\
590\end{array}$ & $\begin{array}{l}422 \\
437 \\
672\end{array}$ \\
\hline $\begin{array}{l}4 \\
5 \\
6\end{array}$ & $\begin{array}{l}\text { Xixabangma } \\
\text { Qiang Yong } \\
\text { Geladaindong }\end{array}$ & $\begin{array}{l}1990-91 \\
1990-91 \\
1988-89 \\
1989-90\end{array}$ & $\begin{array}{l}68 \\
62 \\
25 \\
56\end{array}$ & $\begin{array}{l}152 \\
139 \\
123 \\
154\end{array}$ & $\begin{array}{l}217 \\
169 \\
144 \\
184\end{array}$ \\
\hline 8 & Mustagh Ata & $\begin{array}{l}1990-91 \\
1991-92\end{array}$ & $\begin{array}{l}21 \\
27\end{array}$ & $\begin{array}{l}227 \\
546\end{array}$ & $\begin{array}{l}247 \\
607\end{array}$ \\
\hline
\end{tabular}

* Annual layers were delineated using visible dust layers in the snowpack and seasonal variations in physical stratigraphy, microparticles concentrations, and major ion concentrations. Annual periods run from "end of summer" to "end of summer" layers in the snowpack.

and Mt. Geladaindong) are intermediate between the low values at Ngozumpa Glacier and the high levels at Hispar Glacier and Mustagh Ata. The deposition of particles with diameters ranging from 3 to $7 \mu \mathrm{m}$ accounts for the high rate of dust deposition at Mustagh Ata.

The annual flux of dust at glaciers with 2 or more years of record (i.e., Hispar Glacier, Mt. Geladaindong, and Mustagh Ata) appears to be relatively independent of annual snow accumulation rates. Annual dust deposition on Hispar Glacier varies inversely with annual snow accumulation. Snow accumulation at Mt. Geladaindong increased 2.2 times from 1988-89 to 1989-90, while the dust flux only increased 1.2 times. The annual dust flux at Mustagh Ata more than doubles from 1990-91 to 1991-92 while annual snow accumulation increases less than $30 \%$. These results suggest that at any particular location the variation in atmospheric loading is the main cause of year to year variation in dust deposition.

\section{Discussion}

Each of the 4 separate geographical regions in the highlands of central Asia where snow and ice samples were collected (i.e., eastern Himalaya, Karakoram, south eastern Tibetan Plateau, and northern/western Tibetan Plateau) display distinctive microparticle concentrations, size distributions, and annual dust deposition rates.

Snow chemistry from Ngozumpa Glaciers has very low calcium concentrations and annual fluxes, which we interpret as low Asian dust influence (Wake et al., 1993). The low particle concentrations and low dust deposition rate measured at Ngozumpa Glacier confirm that the southern slopes of the eastern Himalaya are little affected by dust derived from the arid and semi-arid regions of Asia. The barrier created by the Himalaya combined with the predominantly zonal flow above the $500 \mathrm{mb}$ level (Barry and Chorley, 1982), acts to block the influx of dust generated in the arid regions to the north. In addition, dust generated in southwest Asia does not appear to be transported far enough eastward to affect the eastern Himalaya (Middleton, 1989).

High concentrations of particles $<2 \mu$ m characterize eolian dust deposited on Hispar Glacier. Several studies have shown that particles with diameters of $\approx 1 \mu \mathrm{m}$ are resistant to scavenging in the atmosphere (e.g., Radke et al., 1980; McGann and Jennings, 1991). Snow samples with mass sizedistributions which peak at particle diameters of $<1 \mu \mathrm{m}$ and $1-2 \mu \mathrm{m}$ and do not show a peak at $5 \mu \mathrm{m}$ resemble atmospheric aerosol that has traveled long distances (several $1000 \mathrm{Km}$ ) and 
has been well sorted by atmospheric scavenging processes (e.g., Rahn et al., 1977; Schütz, 1980; Steffensen, 1985; Braaten and Cahill, 1986). The timing and mass-size distributions suggest it is unlikely that dust storms in Asia could be the source of particles $<2 \mu \mathrm{m}$ in the Karakoram as we would expect to see strong seasonal signals with maximum dust deposition occurring in spring and/or summer as well as a higher concentration of particles with diameters ranging from $2-10 \mu \mathrm{m}$.

The two mass-size distributions with peaks at $<1 \mu \mathrm{m}$ and 1-2 $\mu \mathrm{m}$ likely represent two separate, distant source regions of mineral aerosol with different chemical characteristics. Calcium rich soils are characteristic of arid regions to the west of the Karakoram (Gomes and Gillette, 1993). Investigations in the Sahara have shown that powdery soils rich in calcium are easily eroded even when the wind intensity is low (Rognon et al., 1989). The calcium rich samples might represent sources to the west of the Karakoram while the calcium poor samples may come from the south-west (i.e., Thar Desert). Future analyses of particle chemistry may help to confirm these hypotheses. The temporal variability in physical and chemical character of dust deposited on the Hispar Glacier does serve.to emphasize the large temporal variability in the size distribution and chemical nature of mineral aerosol transported long distances in the atmosphere.

Two samples collected from a $50 \mathrm{~mm}$ thick dirty ice layer at a depth of $5 \mathrm{~m}$ in the snowpack at Hispar Glacier display unique lognormal mass size distributions which peak at $5 \mathrm{~m}$. Mass-size distributions which peak in the $5 \mu \mathrm{m}$ range are typical of mineral dust samples that have been collected during dust storms (Patterson and Gillette, 1977; Schütz, 1980; Gomes and Gillette, 1993). Based on our chronology, this dirty ice layer was formed in the summer of 1986. In July of 1986, 3 catastrophic landslides occurred in the Bualtar Glacier basin (Hewitt, 1988), approximately $80 \mathrm{~km}$ west of the sample collection site. Each landslide resulted in major dustfall episode which was reported up to $25 \mathrm{~km}$ away. The high concentrations, mass-size distributions and date of this ice layer suggests it represents deposition of dust generated during the 1986 landslides in the Bualtar Glacier basin. Furthermore, the decrease in albedo of the surface due to dust deposition was probably a factor in the formation of the ice layer.
Samples from glaciers in south eastern Tibet (Xixabangma, Qiang Yong Glacier and Mt. Geladaindong) display similar number and mass concentrations. However, Mt. Geladaindong, which lies closer to the arid regions in the northern and western Tibetan Plateau, shows a more distinctive maximum between 3 and $8 \mu \mathrm{m}$ in the mass-size distribution curve (Fig. 4) as well as higher maximum concentrations in summer layers (Fig. 2). The spatial variation in dust deposition characteristics in south eastern Tibet suggest that the source area consists primarily of semi-arid and arid regions in the western and northern portions of the Tibetan Plateau and/or the deserts on the northern margin of the plateau.

The relatively high concentrations and lognormal mass-size distribution, centered at 3 to $8 \mu \mathrm{m}$ diameters, of particles measured in samples from Mustagh Ata and Chongce Ice Cap in the western regions of the Tibetan Plateau are indicative of the influx of dust from local and/or regional sources such as the surrounding arid landscape and the Taklamakan desert. The Kara Kum and other deserts in Tajikistan, Kyrgyzstan and southern Kazakhstan could also act as additional source areas for the western regions of the Tibetan Plateau.

\subsection{Annual dust deposition}

There is a conspicuous lack of modern dust deposition measurements in remote regions of the continents (Prospero, 1990; Schütz et al., 1990). Here we compare our results with those that appear in the published literature for mid-latitude continental sites.

The annual deposition rate of dust shows a more than ten-fold variation between the four geographic regions in the highlands of central Asia (Table 3). The annual dust deposition measured at Ngozumpa Glacier is similar to that reported for Midway $\left(64 \mu \mathrm{g} \mathrm{cm}^{-2} \mathrm{yr}^{-1}\right)$ and Oahu $(43 \mu \mathrm{g}$ $\mathrm{cm}^{-2} \mathrm{yr}^{-1}$ ) in the north Pacific (Uematsu et al., 1985), the Olympic Mountains in Washington State (32-43 $\mu \mathrm{g} \mathrm{cm}^{-2} \mathrm{yr}^{-1}$; Windom, 1969), and in the Swiss Alps $\left(60 \mu \mathrm{g} \mathrm{cm}^{-2} \mathrm{yr}^{-1}\right.$; Wagenbach and Geis, 1989). The annual dust flux at Hispar Glacier and Mustagh Ata are comparable to those measured in Japan (500 to $1000 \mu \mathrm{g} \mathrm{cm}^{-2} \mathrm{yr}^{-1}$; Inoue and Naruse, 1987). The highest depositional rates we measured in the mountains of central Asia are still much less than rates reported for 
Corsica $\left(1,700 \mu \mathrm{g} \mathrm{cm}^{-2} \mathrm{yr}^{-1}\right.$; Loye-Pilot et al., 1986), Beijing $\left(24,000 \mu \mathrm{g} \mathrm{cm}^{-2} \mathrm{yr}^{-1}\right.$; Liu et al., 1981), Tajikistan $\left(29,000-49,000 \mu \mathrm{g} \mathrm{cm}^{-2} \mathrm{yr}^{-1}\right.$; Gillette and Dobrowolski, 1993), Texas $(26,000-$ $28,000 \mu \mathrm{g} \mathrm{cm}^{-2} \mathrm{yr}^{-1}$; Smith et al., 1970), Arizona $\left(54,000 \mu \mathrm{g} \mathrm{cm}^{-2} \mathrm{yr}^{-1}\right.$; Péwé et al., 1981), northern Nigeria $\left(13,700-181,000 \mu \mathrm{g} \mathrm{cm}^{-2} \mathrm{yr}^{-1}\right.$; McTainish and Walker, 1982), and Chad $(109,000$ $\mu \mathrm{g} \mathrm{cm}^{-2} \mathrm{yr}^{-1}$; Maley, 1980). It appears that high elevation accumulation zones in central Asian glaciers are not a major sink for airborne dust generated in the arid and semi-arid landscapes of central Asia. However, the dominance of particles with diameters $<2 \mu \mathrm{m}$ in the mass-size distributions at Hispar Glacier suggests that the Karakoram is an important sink for mineral aerosol which has been transported long distances in the atmosphere. While it appears that dust deposition is not directly related to snow accumulation (Table 3 ), the processes which are responsible for high snow accumulation in the Karakoram (i.e., orographic lifting of westerly derived air masses) may also be responsible for removal of particles $<2 \mu \mathrm{m}$ in diameter.

\section{Conclusions}

Analysis of the spatial and temporal variation in the dust content of glaciers provides valuable data for investigating sources, transport, and deposition of mineral aerosol in central Asia. The observed variation of insoluble particle concentrations, size distributions, and annual deposition in central Asia are dependent upon physiographic location of the sampling site with respect to source regions of dust and atmospheric transport pathways. The microparticle data presented in this paper defines four distinct "dust deposition" regions in the highlands of central Asia (i.e., the southern slopes of eastern Himalayas, the Karakoram, and the south-eastern and northwestern regions of the Tibetan Plateau). Each region is characterized by different source areas of dust and/or different transport pathways from source to sampling site.

Glaciers in the eastern Himalaya, the
Karakoram and the south eastern regions of the Tibetan Plateau contain records of dust deposition that are representative of conditions in the upper troposphere and little affected by boundary layer air. Snow samples from the southern slopes of the eastern Himalaya contain particle concentrations and size distributions similar to those measured in Greenland and dust deposition rates comparable to those measured at remote oceanic sites. Our data suggest that dust records from the eastern Himalaya provide a measure of background mineral aerosol loading in the northern hemisphere. The Karakoram appears to be a major sink for long traveled mineral aerosol particles $<2 \mu \mathrm{m}$ and thus provides a different northern hemisphere signal than that available from the eastern Himalayas. Glaciers in southern and central regions of the eastern Tibetan Plateau record the influx of dust generated in the arid and semi-arid regions of western China and therefore provide dust deposition records of regional (i.e., Asian) significance. Glaciers in the northern and western regions of the Tibetan plateau provide dust deposition records mainly of local significance. High elevation glaciers in the eastern Himalayas, Karakoram and south eastern Tibetan Plateau are therefore most likely to provide long-term $\left(10^{2}\right.$ to $10^{4}$ years) dust deposition records which reflect regional to hemispheric signals.

\section{Acknowledgments}

We thank Grant Mershon, Lynne Fosberry, and Rick Neier for help with analyses of microparticles and data reduction. The comments of Jack Dibb, Nancy Kinner and Robert Talbot on earlier versions of the manuscript are greatly appreciated. The research in China was supported by the U.S. NSF division of Atmospheric Chemistry (ATM-9014768) and Academia Sinica, P. R. China, in Pakistan by Wilfrid Laurier University and the Inernational Development Research Center (Canada), and in Nepal by the General Electric Company (England) Young Employees Nepal 1990 Expedition and Tribhuvan University (Kathmandu). 


\section{REFERENCES}

Alekseyev, B. A. et al., 1988. Geographic belts and zonal types of landscapes of the world. Scale 1:15,000,000. School of Geography, Moscow State University, Moscow.

Barry, R. G. and Chorely, R. J. 1982. Atmosphere, Weather \& Climate, 4th edition, Methuen, New York, 407 pp.

Barry, R. G. 1981. Mountain weather and climate. Methuen, New York, $313 \mathrm{pp}$.

Blank, M., Leinen, M. and Prospero, J. M. 1985. Major Asian aeolian inputs indicated by the mineralogy of aerosols and sediments in the western Pacific. Nature 314, 84-86.

Braaten, D. A. and Cahill, T. A. 1986. Size and composition of Asian dust transported to Hawaii. Atmos. Environ. 20, 1105-1109.

De Angelis, M., Barkov, N. I. and Petrov, V. N. 1987. Aerosol concentrations over the last climatic cycle (160 kyr) from an Antarctic ice core. Nature 325, 318-321.

Domrös, M. and Peng, G. 1988. The climate of China. Springer-Verlag, New York, 361 pp.

Duce, R. A., Unni, C. K. and Ray, B. J. 1980. Long-range atmospheric transport of soil dust from Asia to the tropical north Pacific: Temporal variability. Science 209, 1522-1524.

Fiacco, R. J. 1991. Microparticles as a paleovolcanic indicator in the 1989 GISP2 firn and ice core. MSc Thesis, $138 \mathrm{pp}$, University of New Hampshire, Durham, NH, USA.

Fiacco, R. J., Palais, J. M., Germani, M. S., Zelinski, G. A. and Mayewski, P. A. 1993. Characteristics and possible source of a 1479 A.D. volcanic ash layer in a Greenland ice core. Quat. Res. 39, 267-273.

Finsterwalder, R. 1960. German glaciological and geological expeditions to the Batura Mustagh and Rakaposhi Range. J. Glaciol. 3, 787-788.

Gao, Y., Arimoto, R., Duce, R. A., Lee, D. S. and Zhou, M. Y. 1992a. Input of atmospheric trace elements and mineral matter to the Yellow Sea during the spring of a low-dust year. J. Geophys. Res. 97, 3767-3777.

Gao, Y., Arimoto, R., Zhou, M. Y., Merrill, J. T. and Duce, R. A. 1992b. Relationships between the dust concentration over eastern Asia and the remote north Pacific. J. Geophys. Res. 97, 9867-9872.

Gillette, D. A. and Dobrowolski, J. P. 1993. Soil formation by dust deposition at Shaartuz, Tadzhik, SSR. Atmos. Environ. 27A, 2519-2526.

Gomes, L. and Gillette, D. A. 1993. A comparison of characteristics of aerosol from dust storms in central Asia with soil-derived dust from other regions. Atmos. Environ. 27A, 2539-2544.

Goudie, A. S. 1983. Dust storms in space and time. Prog. Phys. Geog. 7, 502-530.

Hammer, C. U., Clausen, H. B., Dansgaard, W., Neftel, A., Kristinsdottir, P. and Johnson, E. 1985. Continuous impurity analysis along the DYE 3 deep core.
In: Greenland ice core: geophysics, geochemistry and the environment (Geophysical Monograph 33) (ed. C. C. Langway, H. Oeschger and W. Dansgaard). American Geophysical Union, Washington, DC, 90-94.

Han, J., Zhou, T. and Nakawo, M. 1989. Stratigraphic and structural features of ice cores from Chongce Ice Cap, West Kunlun Mountains. Bull. Glacier Research 7, 21-28.

Hastenrath, S. 1985. Climate and circulation in the tropics. D. Reidel, Boston.

Hewitt, K. 1988. Catastrophic landslide deposits in the Karakoram Himalaya. Science 242, 64-67.

Inoue, J. 1976. Climate of Khumbu Himal. Seppyo 38, 66-73.

Inoue, K. and Naruse, T. 1987. Physical, chemical, and mineralogical characteristics of modern eolian dust depostion in Japan and rate of dust deposition. Soil Sci. Plant Nutr. 33, 327-345.

Iwasaka, Y., Minoura, H. and Nagaya, K. 1983. The transport and spatial scale of Asian dust-storm clouds: a case study of the dust-storm event of April 1979. Tellus 35B, 189-196.

Junge, C. E. 1963. Air chemistry and radioactivity. Academic Press, New York.

Junge, C. E. 1979. The importance of mineral dust as an atmospheric constituent. In: Saharan dust: mobilization, transport, deposition. SCOPE Report 14 (ed. C. Morales). John Wiley \& Sons, New York, 49-60.

Koerner, R. M. 1977. Distribution of microparticles in a 299-m core through the Devon Island ice cap, Northwest Territories, Canada. IAHS Pub. no. 118, 371-376.

Liu, T. S. 1985. Loess and the environment. China Ocean Press, Beijing, $251 \mathrm{pp}$.

Liu, T. S., Gu, X. F., An, Z. S. and Fan, Y. X. 1981. The dust fall in Beijing, China on April 18, 1980. In: Desert dust: origin, characteristics, and effect on man (ed. T. L. Péwé). Geological Society of America Special Paper 186, 149-157.

Loÿe-Pilot, M. D., Martin, J. M. and Morelli, J. 1986. Influence of Saharan dust on the rain acidity and atmospheric input to the Mediterranean. Nature 321, 427-428.

Maley, J. (1980). Les changements climatiques de la fin du tértiare en Afrique: leur consequence sur l'apparition du Sahara et de sa végetation. In: The Sahara and the Nile (ed. J. Williams and H. Faure). Balkema, Rotterdam, The Netherlands, 63-86.

McGann, B. T. and Jennings, S. G. 1991. The efficiency with which drizzle and precipitation sized drops collide with aerosol particles. Atmos. Environ. 25A, 791-799.

McTainsh, G. and Walker, P. H. 1982. Nature and distribution of Harmattan dust. Z. Geomorph. NF 26, 417-436.

Mayewski, P. A., Lyons, W. B., Ahmad, N., Smith, G. 
and Pourchet, M. 1984. Interpretation of the chemical and physical time-series retrieved from Sentik Glacier, Ladakh Himalaya, India. J. Glaciol. 30, 66-76.

Merrill, J. T., Uematsu, M. and Bleck, R. 1989. Meteorological analysis of long range transport of mineral aerosol over the north Pacific. J. Geophys. Res. 94, 8584-8598.

Middleton, N. J. 1986. A geography of dust storms in south-west Asia. J. Climatology 6, 183-196.

Middleton, N. J., Goudie, A. S. and Wells, G. L. 1986. The frequency and source areas of dust storms. In: Aeolian geomorphology (ed. W. G. Nickling). Allen \& Unwin, Boston, 237-259.

Middleton, N. J. 1989. Climatic controls on the frequency, magnitude and distribution of dust storms: Examples from India/Pakistan, Mauritania and Mongolia. In: Paleoclimatology and paleometeorology: modern and past patterns of global atmospheric transport (ed. M. Leinen and M. Sarnthein). Kluwer Academic Publishers, Boston, 97-132.

Miller, M. M., Leventhal, J. S. and Libby, W. F. 1965. Tritium in Mt. Everest Ice-Annual glacier accumulation and climatology at great equatorial altitudes. J. Geophys. Res. 70, 3885-3888.

Morales, C. 1979. Saharan dust: mobilization, transport, deposition (SCOPE Report \# 14). John Wiley \& Sons, New York.

Murakami, T. 1987. Effects of the Tibetan Plateau. In: Monsoon meteorology (ed. C. P. Chang and T. N. Krishnamurti). Oxford University Press, New York, 235-270.

Palais, J. M., Germani, M. S. and Zelinski, G. A. 1992. Inter-hemispheric transport of volcanic ash from a 1259 A.D. volcanic eruption to the Greenland and Antarctic Ice Sheets. Geophys. Res. Lett. 19, 801-804.

Parrington, J. R., Zoller, W. H. and Aras, N. K. 1983. Asian Dust: Seasonal transport to the Hawaiian Islands. Science 220, 195-197.

Patterson, E. M. and Gillette, D. A. 1977. Commonalities in measured size distributions for aerosols having a soil-derived component. J. Geophys. Res. 82, 2074-2082.

Petit, J. R., Mounier, L., Jouzel, J., Korotkevich, Y. S., Kotlyakov, V. I. and Lorius, C. 1990. Palaeoclimatological and chronological implications of the Vostok core dust record. Nature 343, 56-58.

Péwé, T. L., Péwé, E. A., Péwé, R. H., Journaux, A. and Slatt, R. M. 1981. Desert dust: Characteristics and rates of depositions in central Arizona, USA. In: Desert dust (ed. T. L. Péwé). Geological Society of America Special Paper 186, 169-190.

Prospero, J. M., Charlson, R. J., Mohnen, V., Jaenicke, R., Delany, A. C., Moyers, J., Zoller, W. and Rahn, K. 1983. The atmospheric aerosol system: an overview. J. Geophys. Res. 21, 1607-1629.

Prospero, J. M. 1990. Mineral-aerosol transport to the north Atlantic and north pacific: the impact of African and Asian sources. In: The long-range atmospheric transport of natural and contaminant substances (NATO ASI Series C, Vol. 297) (ed. A. H. Knap). Kluwer Academic Publishers, Boston, 59-86.

Pye, K. 1987. Aeolian dust and dust deposits. Academic Press, New York, 334 pp.

Ramage, C. S. 1971. Monsoon meteorology. Academic Press, New York, 296 pp.

Rahn, K., Borys, R. D. and Shaw, G. E. 1977. The Asian source of Arctic haze bands. Nature 268, 713-715.

Radke, L. F., Hobbs, P. V. and Eltgroth, W. M. 1980. Scavenging of aerosol particles by precipitation. J. Appl. Meteor. 19, 715-722.

Rea, D., Leinen, M. and Janecek, T. 1985. Geologic approach to the long-term history of atmospheric circulation. Science 227, 721-725.

Rognon, P., Coudé-Gaussen, G., Bergametti, G. and Gomes, L. 1989. Relationships between the characteristics of soil, the wind energy and dust near the ground, in the western sandsea (NW Sahara). In: Paleoclimatology and paleometeorology: modern and past patterns of global atmospheric transport (NATO ASI Series C, Vol. 282) (ed. M. Leinen and M. Sarnthein). Kluwer Academic Publishers, Boston, 167-184.

Schütz, L. and Jaenicke, R. 1974. Particle number and mass distributions above $10^{-4} \mathrm{~cm}$ radius in sand and aerosol of the Sahara desert. J. Appl. Meteor. 13, 863-870.

Schütz, L. 1980. Long range transport of desert dust with special emphasis on the Sahara. In: Aerosols: anthropogenic and natural; sources and transport (ed. T. J. Kneip and P. J. Lioy). Annals New York Academy Science, New York, 515-532.

Schütz, L., Buat-Ménard, P., Carvalho, R., Cruzado, A., Harriss, R., Heidam, N., Jaenicke, R. and Prospero, J. 1990. The long-range transport of mineral aerosols. In: The long-range atmospheric transport of natural and contaminant substances (NATO ASI Series C, Vol. 297) (ed. A. H. Knap). Boston: Kluwer Academic Publishers, 197-229.

Smith, R. M., Twiss, P. C., Krauss, R. K. and Brown, M. J. 1970. Dust deposition in relation to site, season, and climatic variables. Soil Sci. Soc. Am. Proc. 34, 112-117.

Steffensen, J. P. 1985. Microparticles in snow from the South Greenland ice sheet. Tellus 37B, 286-295.

Thompson, L. G., Mosley-Thompson, E., Davis, M. E., Bolzan, J. F., Dai, J., Yao, T., Gundestrup, N., Wu, X., Klein, L. and Xie, Z. 1989. Holocene-Late Pleistocene climatic ice core records from Qinghai-Tibetan Plateau. Science 246, 474-477.

Thompson, L. G., Wu, X., Mosley-Thompson, E. and Xie, Z. 1988. Climatic records from the Dunde Ice Cap, China. Annal. Glaciol. 10, 178-182.

Uematsu, M., Duce, R. A., Prospero, J. M., Chen, L., Merrill, J. T. and McDonald, R. 1983. Transport of mineral aerosol from Asia over the north Pacific. J. Geophys. Res. 88, 5343-5352. 
Uematsu, M., Duce, R. and Prospero, J. 1985. Deposition of atmospheric mineral particles in the north Pacific Ocean. J. Atmos. Chem. 3, 123-138.

Wagenbach, D. and Geis, K. 1989. The mineral dust record in a high altitude alpine glacier (Colle Gnigetti, Swiss Alps). In: Paleoclimatology and paleometeorology: modern and past patterns of global atmospheric transport (NATO ASI Series C, Vol. 282) (ed. M. Leinen and M. Sarnthein). Kluwer Academic Publishers, Boston, 543-564.

Wake, C. P. 1989. Glaciochemical investigations as a tool for determining the spatial and seasonal variation of snow accumulation in the central Karakoram, northern Pakistan. Ann. Glaciol. 13, 279-284.

Wake, C. P., Mayewski, P. A. and Spencer, M. J. 1990. A review of central Asian glaciochemical data. Annal. Glaciol. 14, 301-306.

Wake, C. P., Mayewski, P. A., Wang, P., Yang, Q., Han, J. and Xie, Z. 1992 Anthropogenic sulfate and Asian dust signals in snow from Tien Shan, northwest China. Annal. Glaciol. 16, 45-52.

Wake, C. P., Mayewski, P. A., Xie, Z., Wang, P. and $\mathrm{Li}, \mathrm{Z}$. 1993. Regional variation of monsoon and desert dust signals recorded in Asian glaciers. Geophys. Res. Lett. 20, 1411-1414.

Wake, C. P., Dibb, J. E., Mayewski, P. A., Xie, Z., Li, Z., Ping, W. and Qin, D. The chemical composition of aerosols over the eastern Himalaya and Tibetan Plateau during low dust periods. Atmos. Environ., in press.

Welch, H. E., Muir, D. C. G., Billeck, B. N., Lockhart, W. L., Brunskill, G. J., Kling, H. J., Olson, M. P. and Lemoine, R. M. 1991. Brown snow: a long-range transport event in the Canadian Arctic. Environ. Sci. Technol. 25, 280-286.

Windom, H. L. 1969. Atmospheric dust records in permanent snowfields: implications for marine sedimentation. Geol. Soc. Am. Bull. 80, 761-782. 